\title{
ORIGINAIS
}

\section{Postmaturity in the Rat: Impairment of Insulin, Glucagon, and Glycogen Stores*}

\author{
B. Portha, G. Rosselin and L. Picon \\ Laboratoire de Physiologie Animale, Bâtiment L, Université Paris VII \\ and Unité de Recherches de Diabétologie et d'Etudes Radio-Immunologiques des Hormones Protéiques, U. 55 \\ (Institut National de la Santé et de la Recherche Médicale), Hôpital Saint-Antoine, Paris, France
}

Summary. Prolonged gestation ( 2 extra days in utero) was obtained by daily subcutaneous injection of progesterone $(2.5 \mathrm{mg})$ to pregnant rats from day 20.5 post coitum (p. c.) through day 22.5 p. c. after reduction of the litter to 6 fetuses on day 14.5 p. c.. Exogenous progesterone per se or litter reduction were without effect on fetal pancreas or fetal liver. Plasma insulin, insulin and glucagon in the pancreas, and liver glycogen stores have been systematically measured in postmature animals and in controls during the perinatal period. In 23.5 day-old postmature as compared to 21.5 day-old normal fetuses, the intrauterine mortality was increased $(26 \%)$, the body weight was increased by $30 \%$, the liver weight was decreased by $20 \%$, the glycogen content of liver was dramatically depleted $(1.1 \pm 0.2 \mathrm{mg} / \mathrm{g}$ body weight on day $23.5 \mathrm{p}$. c. against $6.7 \pm 0.3$ on day $21.5 \mathrm{p} . \mathrm{c}$.), the plasma insulin was lowered by $63 \%$ and the blood glucose level was normal. In postmature neonates during the first day of life the mortality rate was considerable $(40 \%)$ and a dramatic fall of blood glucose was observed 6 hours after birth. The accumulation of insulin and glucagon in the pancreas, which normally occurs in the two first days after birth, was much lower in the postmature fetuses: in 23.5 day-old fetuses as compared to 2 day-old normal newborns of the same gestational age the insulin content was only $50 \%$ and the glucagon content $69 \%$. The deficit of insulin accumulation in the postmature pancreas lasted at least five days. The ability of the endocrine pancreas to recover from this alteration was well shown by the lack of diabetes when the animals were examined three weeks later by a glucose tolerance test. These findings suggest that the drop of plasma insulin is a prime factor in causing the

\footnotetext{
* This work has previously been presented at the 11 th Meeting of the European Association for the Study of Diabetes, Munich, September $1975(1)$.
}

lack of glycogen stores in prolonged fetuses and the impairment of glycogen stores appears to be an important feature of postmaturity, since neonates exhibit, in these conditions, a lethal drop of blood glucose as glycogenolysis operates on very low glycogen stores.

Key Words: Insulin, glucagon, glycogen, blood glucose, progesterone, fetus, neonate, placenta, postmaturity, neonatal hypoglycemia.

In the human, the incidence of postmaturity is about five percent and is considered to be, after prematurity, the major cause of fetal and neonatal mortality [2]. Whereas in the human postmature fetus modifications of placental weight [3], histological pattern [3], and transfer of water and electrolytes [4], which have been classified as placental insufficiency, have been observed, no systematic study has been done concerning the nutritional and hormonal conditions. However, hypoglycemia has been mentioned in the postmature human neonate $[5,6]$.

In experimental delayed gestation in the rat, histological arguments suggest that the size of fetal pancreatic islets is reduced [7], glycogen in fetal hepatocytes is scarce [8] and the adrenal cortex is hypertrophied [9, 10]. Experimental prolonged gestation can be obtained in the rat by exogenous progesterone. We have chosen this model to investigate the modifications induced by postmaturity on the liver and endocrine pancreas during the perinatal period without losing sight of the fact that the effects of prolonged gestation in the human and in the rat have to be interpreted with caution considering species - different placentation [3]. Because of the defect in insulin 
stores that we have observed in experimental postmaturity it was of interest to check the long term effect of post maturity on the insulin stores and glucose disposal after birth.

\section{Materials and Methods}

Animals. Albino rats (Sherman strain) bred in the laboratory were fed ad libitum with pelleted chow (U. A. R., B 03; carbohydrate $47 \%$, protein $20 \%$, fat $8 \%$ ). Females were caged with a male for one night (5 p. m. to 9 a. m.) and pregnancy was detected by abdominal palpation 14 days later.

Prolonged Gestation. Parturition was delayed with progesterone (Lutogyl, Roussel, France) administered subcutaneously to the mother $(2.5 \mathrm{mg}$ per animal) once daily on day $20.5,21.5$, and 22.5 of gestation. In control experiments, progesterone injections were given on day 18.5, 19.5, and 20.5. Pregnant females were subjected to a first laparotomy on day 14.5 post coïtum (p. c.) in order to reduce large litters to 6 fetuses, because prolonged gestation was not well tolerated when there were too many fetuses in the uterus [11]. The effects of the reduction of the litter to 6 fetuses on body weight, liver glycogen, blood glucose and pancreatic hormones have also been investigated. No significant change was observed in the parameters studied with reduced litters or normal litters ( 8 to 12 fetuses) as indicated in Table 1 . This result is in accordance with unchanged prenatal development in the rat when litters are restricted on day 8 of gestation, with more than $50 \%$ of the litter remaining [12].

Fetuses. Fetuses were obtained as follows: the pregnant rat was anaesthetized by sodium pentobarbitone (4 $\mathrm{mg}$ per $100 \mathrm{~g}$ body weight intraperitoneally) and the fetuses were successively extracted from the uterus, leaving the placenta and umbilical cord in situ. Maternal samples were drawn from the dorsal aorta.

Newborn. Natural birth generally occurred twentytwo days after mating and lasted up to 2 hours. Since precise timing of birth and sampling was desired, all the newborn animals were obtained by caesarean section after killing the mother by cervical dislocation. In normal gestation, caesarean section was performed on day 21.5 p. c. and in prolonged gestation on day 22.5 p. c. and 23.5 p. c. In some experiments, newborn were immediately transferred to a moist incubator at $36^{\circ} \mathrm{C}$ and kept fasting for the duration of the study.

In other experiments, newborn were left with foster mothers, with the number of animals per litter kept at 6 , since the size of the litter has a short [13] and a long-term [14] influence on body weight and insulin release.

Samples. Fetal or neonatal blood samples were collected from axillary vessels and immediately centrifuged at $4^{\circ} \mathrm{C}$; plasma was stored at $-20^{\circ} \mathrm{C}$ until assayed. After dissection, the pancreas was weighed and homogenized for one minute by ultrasonic disintegration at $4^{\circ} \mathrm{C}$ (Branson Sonifier B. 12, Connecticut) in acid alcohol solution ( $75 \% \mathrm{v} / \mathrm{v}$ ethanol, $1.5 \%$ $\mathrm{v} / \mathrm{v} 12 \mathrm{~N} \mathrm{HCl}, 23.5 \%$ distilled water). After centrifugation, the supernatant was kept at $-20^{\circ} \mathrm{C}$ until assay. The liver and placenta were rapidly removed, weighed and submitted to glycogen extraction.

Intravenous glucose tolerance test $(2 \mathrm{~g}$ glucose $/ \mathrm{kg}$ body weight) was carried out by an injection through the saphenous vein. Blood samples were collected by puncture of the orbital venous plexus just before, 15 and 90 minutes after injection for assay of glucose and immunoreactive insulin (IRI). No modification in the blood glucose or insulin levels measured at these post injection time intervals was observed in control animals injected with saline.

Assays. Blood glucose was measured by the glucose oxidase procedure [15] and glycogen as previously described [16]. Pancreatic and plasma IRI were estimated using purified rat insulin as standard (18 IU/mg, Dr. A. Lambert), antibody to human insulin [17] and ${ }^{131}$ I-human insulin (Centre National de Transfusion Sanguine, Paris). Immunoreactive glucagon (IRG) was assayed in the pancreas according to the method previously described [18] using porcine ${ }^{125} \mathrm{I}$-glucagon as tracer and porcine glucagon as standard (Novo B 66 K 1070), Dr. J. Schlichtkrull). Silicate was used to separate free from bound hormone [19]. Statistical analysis were performed using Student's unpaired t-test.

\section{Results}

Parturition was delayed with progesterone as indicated above. In order to distinguish the effects of prolonged gestation from the modifications likely to be related to progesterone, the effect of progesterone per se, without prolonged gestation, was analysed. Results obtained in 21.5 day old fetuses whose mothers were submitted to three progesterone injections on day 18,19 and 20 of gestation have been compared to those observed in normal 21.5 day old controls (Table 2). Three progesterone injections do not significantly change plasma and pancreatic IRI, pancreatic IRG, liver glycogen, blood glucose or body 
Table 1. Effect of operative restriction of the litter on the fetus

\begin{tabular}{lllllll}
\hline & $\begin{array}{l}\text { Body weight } \\
\mathrm{g}\end{array}$ & $\begin{array}{l}\text { Liver glycogen } \\
\mathrm{mg} / \mathrm{g}\end{array}$ & $\begin{array}{l}\text { Blood glucose } \\
\mathrm{mg} / 100 \mathrm{ml}\end{array}$ & $\begin{array}{l}\text { Plasma IRI } \\
\mu \mathrm{U} / \mathrm{ml}\end{array}$ & $\begin{array}{l}\text { Pancreatic IRI } \\
\mathrm{mU} / \mathrm{mg}\end{array}$ & $\begin{array}{l}\text { Pancreatic IRG } \\
\mathrm{ng} / \mathrm{mg}\end{array}$ \\
\hline Controls & $5.2 \pm 0.1$ & $103 \pm 3$ & $58 \pm 3$ & $326 \pm 54$ & $5.9 \pm 0.7$ & $14.9 \pm 1.2$ \\
Reduced litters & $(6)$ & $(6)$ & $(6)$ & $(9)$ & $(6)$ & $(6)$ \\
& $5.0 \pm 0.1$ & $105 \pm 4$ & $64 \pm 3$ & $355 \pm 44$ & $5.9 \pm 1.4$ & $12.2 \pm 1.2$ \\
$(6)$ & $(6)$ & $(6)$ & $(6)$ & $(6)$ & $(6)$ \\
\hline
\end{tabular}

Litter reduction to 6 fetuses was performed on day 14.5 p. c. and the variables studied on day 21.5 p. c. The values are the means \pm SEM. Figures in parentheses indicate the number of observations.

Table 2. Effect on the fetus of progesterone injected to the mother

\begin{tabular}{lllllll}
\hline & $\begin{array}{l}\text { Body weight } \\
\mathrm{g}\end{array}$ & $\begin{array}{l}\text { Liver glycogen } \\
\mathrm{mg} / \mathrm{g}\end{array}$ & $\begin{array}{l}\text { Blood glucose } \\
\mathrm{mg} / 100 \mathrm{ml}\end{array}$ & $\begin{array}{l}\text { Plasma IRI } \\
\mu \mathrm{U} / \mathrm{ml}\end{array}$ & $\begin{array}{l}\text { Pancreatic IRI } \\
\mathrm{mU} / \mathrm{mg}\end{array}$ & $\begin{array}{l}\text { Pancreatic IRG } \\
\mathrm{ng} / \mathrm{mg}\end{array}$ \\
\hline Controls & $5.0 \pm 0.1$ & $97 \pm 7$ & $58 \pm 6$ & $289 \pm 23$ & $4.6 \pm 0.4$ & $15.2 \pm 1.2$ \\
Pg-treated & $(6)$ & $(6)$ & $(12)$ & $(6)$ & $(8)$ & $(7)$ \\
& $5.1 \pm 0.1$ & $90 \pm 4$ & $63 \pm 2$ & $290 \pm 30$ & $5.0 \pm 0.5$ & $14.6 \pm 0.9$ \\
$(12)$ & $(8)$ & $(14)$ & $(8)$ & $(2)$ \\
\hline
\end{tabular}

Subcutaneous progesterone injection was performed daily on day $18.5,19.5$ and 20.5 p. c. Fetal variables were studied on day 21.5 p. c. The values are the means \pm SEM. Figures in parentheses indicate the number of observations.

Table 3. Effect of prolonged pregnancy on the growth of the fetuses

\begin{tabular}{|c|c|c|c|c|c|c|c|}
\hline \multirow[t]{2}{*}{ Concept. age } & \multicolumn{2}{|c|}{$\begin{array}{l}\text { Body weight } \\
\text { g }\end{array}$} & \multicolumn{2}{|c|}{$\begin{array}{l}\text { Pancreas weight } \\
\text { mg }\end{array}$} & \multicolumn{2}{|c|}{$\begin{array}{l}\text { Liver weight } \\
\mathrm{mg}\end{array}$} & \multirow[t]{2}{*}{$\begin{array}{l}\text { Placental weight } \\
\text { g }\end{array}$} \\
\hline & A & B & A & B & A & B & \\
\hline 21.5 & $\begin{array}{l}5.0 \pm 0.1 \\
(30)\end{array}$ & - & $\begin{array}{l}15 \pm 1 \\
(60)\end{array}$ & - & $\begin{array}{l}295 \pm 6 \\
(30)\end{array}$ & - & $\begin{array}{l}455 \pm 15 \\
(12)\end{array}$ \\
\hline 22.5 & $\begin{array}{l}5.2 \pm 0.1 \\
(39)\end{array}$ & $\begin{array}{l}5.8 \pm 0.1 \\
(14)\end{array}$ & $\begin{array}{l}16 \pm 1 \\
(15)\end{array}$ & $\begin{array}{l}15 \pm 1 \\
(5)\end{array}$ & $\begin{array}{l}218 \pm 15 \\
(5)\end{array}$ & $\begin{array}{l}200 \pm 10 \\
(5)\end{array}$ & - \\
\hline 23.5 & $\begin{array}{l}6.4 \pm 0.1 \\
(45)\end{array}$ & $\begin{array}{l}6.4 \pm 0.1 \\
(48)\end{array}$ & $\begin{array}{l}18 \pm 1 \\
(51)\end{array}$ & $\begin{array}{l}16 \pm 1 \\
(58)\end{array}$ & $\begin{array}{l}236 \pm 11 \\
(27)\end{array}$ & $\begin{array}{l}181 \pm 9 \\
(6)\end{array}$ & $\begin{array}{l}487 \pm 23 \\
(16)\end{array}$ \\
\hline
\end{tabular}

Column A represents the fetuses and column B the newborns of the same conceptional age delivered by cesarean section on day 21.5 p. c. and given to foster mothers. The values are the means \pm SEM. The number of observations is shown in parentheses.

weight. These results suggest that exogenous progesterone has no effect on the different variables considered. The maternal metabolic situation appeared to be affected little or not at all by the progesterone treatment. The animals were fed ad libitum until the time of caesarean section. Body weight during the last three days of gestation (from day 18.5 up to day 21.5 for the normal pregnant animals, from day 20.5 up to day 23.5 for the "prolonged" animals) was not different in the two groups. Despite the fact that food intake appeared to be slightly reduced in the "prolonged" group (17.3 $\pm 1.2 \mathrm{mg}$ pelleted food per day against $24.2 \pm 0.9$ per day in the control group), blood glucose and plasma insulin concentrations were not affected when compared to normal pregnant females: in 23.5 day old mothers, blood glucose was $91 \pm 3$ $\mathrm{mg} / 100 \mathrm{ml}(\mathrm{n}=16)$ and plasma IRI was $56 \pm 11$ $\mu \mathrm{U} / \mathrm{ml}(\mathrm{n}=10)$; in 21.5 day old mothers, blood glucose was $87 \pm 6(n=6)$ and plasma IRI was $59 \pm 3$ $(\mathrm{n}=5)$.

\section{Effect of Prolonged Pregnancy on the Growth of Fetuses}

The incidence of intrauterine mortality increased with lengthening gestation. Whereas no mortality was found with one extra day of gestation, the mortality rate was $26 \%(31 / 120)$ and $37 \%(11 / 30)$ on day 23.5 and 24.5 , respectively. On day 23.5 and day 24.5 amniotic fluids were stained with greenish meconium. Body weight was higher and liver weight lower in "prolonged" fetuses than in those delivered at the right time; on the other hand, pancreas and placenta weights were similar in both these groups (Table 3 ). 

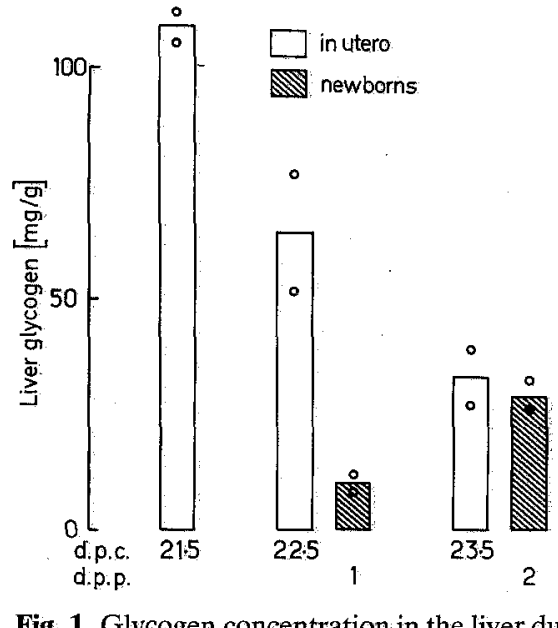

Fig. 1. Glycogen concentration in the liver during prolonged gestation. The values for the fetuses are compared to those of neonates of the same conceptional age delivered on day 21.5. p. c. Mean values and SEM (o) are given. The number of observations is between 6 and 12

Thus, despite the different nutritional conditions, liver weight of "prolonged" fetuses followed a pattern similar to that observed in normal neonates. At the same gestational age, day 23.5 , a decrease of $20 \%$ and $40 \%$, respectively, was observed as compared to the weight on day 21.5 p. c.

\section{Metabolic and Hormonal Effects of Prolonged Pregnancy on Fetuses}

Liver glycogen content decreased during prolonged pregnancy from $109 \pm 3$ to $64 \pm 13$ and $33 \pm 6 \mathrm{mg} / \mathrm{g}$ of wet weight on day $21.5,22.5$ and 23.5 p. c., respectively. The fall in liver glycogen stores is still more significant when the total glycogen content of liver is compared to body weight because of the simultaneous decrease of both liver glycogen and liver weight: glycogen content in $\mathrm{mg}$ per $\mathrm{g}$ of body weight is $6.7 \pm$ $0.3,2.8 \pm 0.2$ and $1.1 \pm 0.2$ on day $21.5,22.5$ and 23.5 p. c., respectively. In normal neonates, on the first day of life, the total liver glycogen content represents 0.33 $\pm 0.1 \mathrm{mg} / \mathrm{g}$ of body weight, which is a twenty-fold instead of the six-fold decrease observed in the "prolonged" fetus by comparison to the glycogen content on day 21.5. Therefore, the "prolonged" fetus exhibits, "in utero", a decrease in glycogen content. Results in normal neonates are in agreement with well-established mobilisation of glycogen after birth $(20,21,22)$. No significant modification of fetal blood

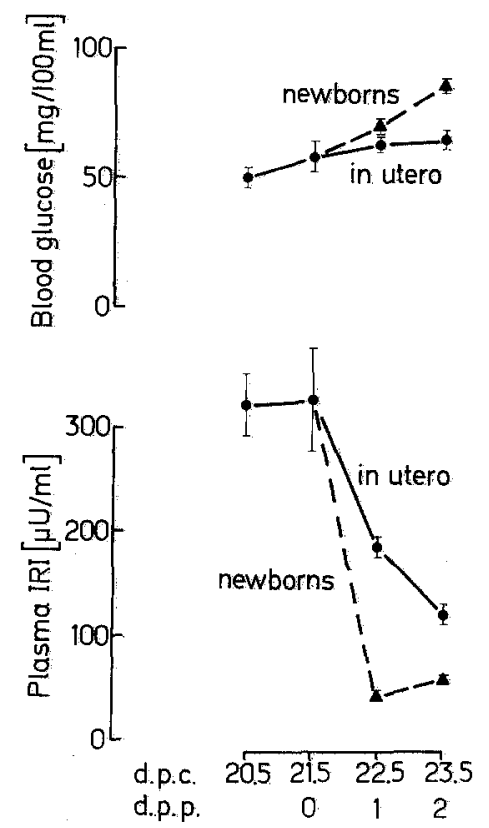

Fig. 2. Changes in blood glucose and plasma insulin in the fetal rat during prolonged gestation. The animals indicated as "newborns" were delivered on day 21.5 p. c.. Mean values and SEM are given. The number of observations is between 8 and 12

glucose was observed in prolonged gestation (Fig. 2): $65 \pm 4$ and $58 \pm 6 \mathrm{mg} / 100 \mathrm{ml}$ on day 23.5 and $21.5 \mathrm{p}$. c., respectively. Plasma insulin decreased sharply from $326 \pm 54 \mu \mathrm{U} / \mathrm{ml}$ on day 21.5 p. c. to $120 \pm 10 \mu \mathrm{U} / \mathrm{ml}$ on day 23.5. In normal neonates, on the first day of life, plasma insulin was $42 \pm 4 \mu \mathrm{U} / \mathrm{ml}$ which is 7.8 -fold instead of the 2.7 -fold decrease observed in the "prolonged" fetuses by comparison to the insulin level on day 21.5. The changes in pancreatic insulin and glucagon content are indicated in Figure 3. In the "prolonged" fetuses, as in newborn, the insulin content of the pancreas increased with age; this increase is smaller in prolonged gestation than after normal birth, with a $40 \%$ increase on day 23.5 p. c., but a $180 \%$ inerease on day 2 post partum (p. p.) as compared to the values on day $21.5 \mathrm{p}$. c. The pancreatic accumulation of glucagon was also lower in the postmature fetuses. Thus, although the physical and metabolic conditions are quite different in "prolonged" fetuses and in neonates, the evolution of the metabolic variables studied is similar in both conditions, with a decrease in liver glycogen content and plasma insulin and an increase in the pancreatic glucagon to insulin ratio.

\section{The Early Postnatal Period of the "Prolonged" Rat}

A high mortality rate was observed in the first day of life of the "prolonged" animals: about $40 \%(13 / 34)$ of the animals died during this period. Lung problems 


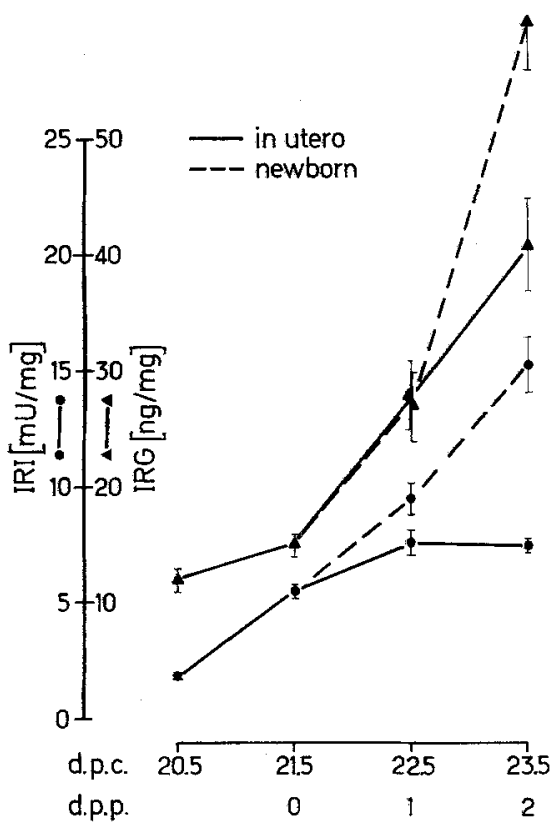

Fig. 3. Effect of prolonged gestation on the insulin and glucagon contents of the fetal pancreas. The animals indicated as "newborn" were delivered on day $21.5 \mathrm{p}$. c. Mean values and SEM are given. The number of observations is between 13 and 46

cannot be involved since breathing is established normally in these neonates. To elucidate the cause of death, sequential changes in liver glycogen, blood glucose and plasma insulin were measured during the first six hours of postnatal life in newborns with prolonged gestation and compared to those occuring in control newborns in the same experimental conditions (Fig. 4). When both groups were kept fasting for six hours blood glucose levels of the "prolonged" animals progressively decreased to very low values, reaching $21 \pm$ $3 \mathrm{mg} / 100 \mathrm{ml}$ six hours after birth. This pattern is completely different from that observed in controls, where the drop of the glucose level was only transient at the first hour $(26 \pm 2 \mathrm{mg} / 100 \mathrm{ml})$ and was followed by a restoration at six hours $(90 \pm 8 \mathrm{mg} / 100 \mathrm{ml})$. The glycogen stores decreased after birth in the "prolonged" group and were almost completely depleted after six hours fasting ( $4 \pm 1 \mathrm{mg} / \mathrm{g}$ liver weight), whereas in neonates, despite attempts at depletion of glycogen stores, $64 \pm 3 \mathrm{mg}$ of glycogen per g of liver remains, 16 times higher than in the "prolonged" group. The fall in liver glycogen stores in the "prolonged" group is even more considerable when results are expressed in terms of total glycogen content: 0.13 $\mathrm{mg} / \mathrm{g}$ of body weight as compared to $3.55 \mathrm{mg} / \mathrm{g}$ of body weight in controls, i. e., a 27 -fold decrease. Plasma insulin fell rapidly after three hours $(37 \pm 6$ $\mu \mathrm{U} / \mathrm{ml}$ ) to values which were similar in the two groups. Thus, it seems likely that the low blood glucose levels
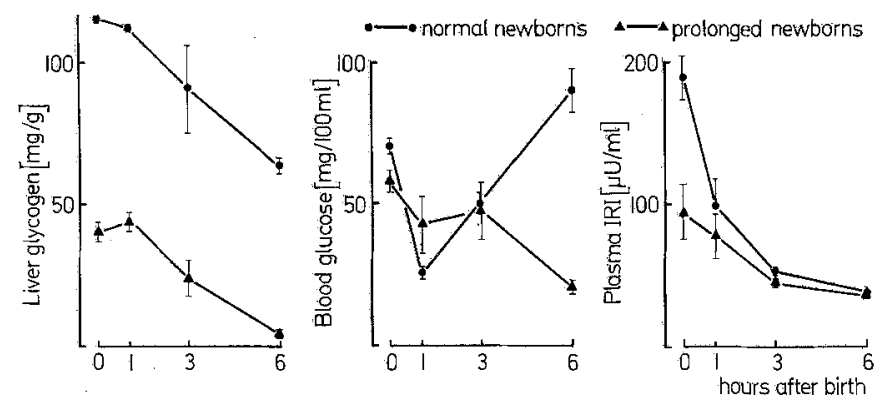

Fig. 4. Effect of prolonged gestation on neonatal glucose disposal. Animals were delivered by caesarean section on day 23.5 p. c. and maintained at normal body temparature during a 6 hour fast starting at birth. Values are the means \pm SEM. The number of observations is between 6 and 8

Table 4. Effect of a 6 hour fast on postmature newborn rats

\begin{tabular}{lllll}
\hline & Body weight & $\begin{array}{l}\text { Liver } \\
\text { Glycogen } \\
\mathrm{mg} / \mathrm{g}\end{array}$ & $\begin{array}{l}\text { Blood } \\
\text { Glucose } \\
\mathrm{mg} / 100 \mathrm{ml}\end{array}$ & $\begin{array}{l}\text { Plasma IRI } \\
\mathrm{g} \mathrm{U} / \mathrm{ml}\end{array}$ \\
\hline Fasted & $6.4 \pm 0.1$ & $3.8 \pm 0.6$ & $22 \pm 4$ & $37 \pm 2$ \\
& $(6)$ & $(6)$ & $(6)$ & $(6)$ \\
Fed & $6.4 \pm 0.2$ & $7.7 \pm 1.8$ & $56 \pm 2$ & $36 \pm 1$ \\
& $(6)$ & $(6)$ & $(6)$ & $(6)$ \\
\hline
\end{tabular}

Animals were delivered by caesarean section on day 23.5 p.c. and remained unfed at normal body temperature. Animals designated as "fed" were given to a foster mother at birth. The values are the means \pm SEM. The number of observations is shown in parentheses.

observed in postmature animals are related to the low liver glycogen content and suggest that this defect in glycogen disposal is responsible for the high neonatal mortality observed in this group.

A similar study was also carried out in postmature animals normally fed by foster mothers after delivery (Table 4). Under these conditions a partial improvement of blood glucose level was observed since six hours after birth the value is $56 \pm 2 \mathrm{mg} / 100 \mathrm{ml}$ against $21 \pm 3 \mathrm{mg} / 100 \mathrm{ml}$ in the fasted state, but exhaustion of glycogen stores was not prevented.

\section{Long Term Effects of Prolonged Gestation}

As described above, prolonged gestation is characterized by a decreased insulin to glucagon ratio in the 
Table 5. Long-term effect of prolonged gestation

\begin{tabular}{|c|c|c|c|c|c|c|c|c|c|}
\hline & \multicolumn{3}{|l|}{ Age } & \multirow{2}{*}{$\begin{array}{l}\text { Concept. } \\
\text { age }\end{array}$} & \multirow{2}{*}{$\begin{array}{l}\text { Body } \\
\text { weight } \\
\mathrm{g}\end{array}$} & \multirow{2}{*}{$\begin{array}{l}\text { Blood } \\
\text { glucose } \\
\mathrm{mg} / 100 \mathrm{ml}\end{array}$} & \multirow{2}{*}{$\begin{array}{l}\text { Plasma } \\
\text { IRI } \\
\mu \mathrm{U} / \mathrm{ml}\end{array}$} & \multicolumn{2}{|l|}{ Pancreatic } \\
\hline & Fetal & & Postnat. & & & & & $\begin{array}{l}\mathrm{IRI} \\
\mathrm{mU} / \mathrm{mg}\end{array}$ & $\begin{array}{l}\text { IRG } \\
\mathrm{ng} / \mathrm{mg}\end{array}$ \\
\hline Controls & 21 & + & 21 & 42 & $\begin{array}{l}39.9 \pm 0.8 \\
(8)\end{array}$ & $\begin{array}{l}93 \pm 6 \\
(6)\end{array}$ & $\begin{array}{l}25 \pm 7 \\
(5)\end{array}$ & $\begin{array}{l}6.9 \pm 0.3 \\
(8)\end{array}$ & $\begin{array}{l}52 \pm 5 \\
(8)\end{array}$ \\
\hline Pg-rats & 23 & + & 19 & 42 & $\begin{array}{l}38.2 \pm 2.6 \\
(10)\end{array}$ & $\begin{array}{l}104 \pm 6 \\
(7)\end{array}$ & $\begin{array}{l}32 \pm 4 \\
(7)\end{array}$ & $\begin{array}{l}6.0 \pm 0.6 \\
(8)\end{array}$ & $\begin{array}{l}56 \pm 4 \\
(8)\end{array}$ \\
\hline
\end{tabular}

Postmature animals were delivered on day $23.5 \mathrm{p}$. c. and given to foster mothers. The variables were studied on day 42 (conceptional age) and compared to the same ones obtained from term-animals delivered on day $21.5 \mathrm{p}$. $\mathrm{c}$. The values are the means $\pm \mathrm{SEM}$ and the number of observations is given in parentheses.
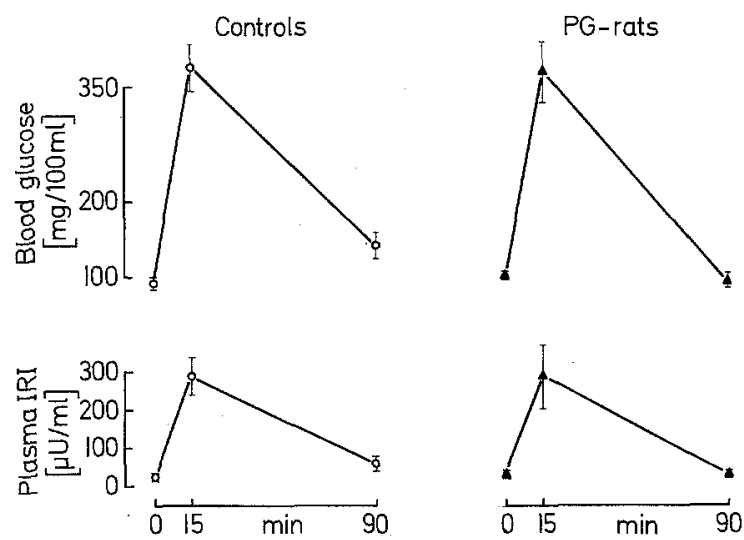

Fig. 5. Effect of glucose load $(2 \mathrm{~g} / \mathrm{Kg}$ intravenously) on plasma insulin and blood glucose levels (mean values \pm SEM) in normal or postmature young rats. PG-rats are postmature rats delivered on day 23.5 p. c. and tested on day 19 after birth. Controls are termrats delivered on day 21.5 p. c. and tested on day 21 after birth. The number of observations is 6

fetal pancreas. We have checked the evolution of this defect in the neonates after prolonged gestation, on day 5 and 19 after birth (Table 5). In the 5 day-old postmature neonates, pancreatic insulin was still $29 \%$ depleted $(13.2 \pm 1.0 \mathrm{mU} / \mathrm{mg}$ against $18.5 \pm 2.4$ $\mathrm{mU} / \mathrm{mg}$ in the controls) and pancreatic glucagon content increased by $85 \%(161 \pm 19 \mathrm{ng} / \mathrm{mg}$ against $87 \pm$ $18 \mathrm{ng} / \mathrm{mg}$ ). No differences were observed in the values obtained on day 19 after birth as compared to the 21 day-old normal neonates. Furthermore, at this age, the insulin response to an in vivo glucose challenge was quite normal, as indicated in Figure 5. In both groups, at corresponding gestational age, body weight, blood glucose and plasma insulin were similar.

\section{Discussion}

This experimental study has revealed four major points which warrant discussion.

The high mortality rate in the postmature newborn can be correlated with the low blood glucose level observed in this group. In normal term neonates transient hypoglycemia was seen within one hour after birth, which is in accordance with the work of others [23]. However, the hypoglycemia observed in the 'postmature neonates' lasted at least six hours and was not reversible by feeding. In the newborn rat, the glycogen stores in the absence of fat stores are the main fuel before the suckling period. In the normal term neonate, the restoration of normal blood glucose levels is well correlated with the development of glycogenolysis and gluconeogenesis in the early neonatal period $[20,21,22,24]$. In the postmature neonate the mobilization of glycogen stores has also been observed. However, the glycogenolysis operates on very low glycogen stores and the depletion of glycogen stores is likely to explain the inability of the postmature newborn to cope with glucose homeostasis.

A decrease in plasma insulin and pancreatic insulin to glucagon ratio was observed in the 'prolonged' fetuses as well as in the term-neonates. Although low blood glucose levels in the term neonate may explain the decreased plasma insulin level, blood glucose cannot account for the lower insulin levels observed in postmature fetuses, since the blood glucose level is similar to that of normal term fetuses. This suggests that low insulin levels in postmature fetuses may be a prime factor in the depletion of glycogen stores. There is some evidence that insulin is a mediator in the synthesis of liver glycogen. In the fetus, in vivo experiments on the rat $[25,26]$, or in vitro experiments using cultured explants of rat or human liver $[27,28] \mathrm{em}-$ phasize the role of insulin in glycogen metabolism. Furthermore, in the adult rat the results obtained with isolated hepatocytes [29] or perfused liver [30] clearly demonstrate direct control by insulin. On the other hand, the effectiveness of glucagon in stimulating liver glucose-6-phosphatase and phosphorylase activities has been considered of importance in the depletion of liver glycogen at birth $[31,32,33,34]$. This mechanism probably accounts for the rapid glycogenolysis after birth in the postmature neonate as in the normal 
term neonate. However, for the moment, although we observed an increased glucagon to insulin ratio in the pancreas, we have no argument to identify glucagon as responsible for the depletion of liver glycogen in the postmature fetus. There is likewise no convergent data about a possible role of glucocorticoids which are known to induce glycogen storage $[27,35,36]$ since it has been observed that fetal rat adrenal cortex is hypertrophied in prolonged gestation $[9,10]$ and in human "postmature neonates" the cortisol level is found to be decreased in cord and neonatal blood [37]. Exogenous progesterone chosen to delay parturition had no effect on the fetus in accordance with the observations of others $[8,9,10]$. Furthermore, at the dose used we found no effect on the maternal plasma insulin level with the progesterone treatment, whereas it has been suggested that the elevated plasma insulin level observed in pregnant or lactating rats is related to increased blood progesterone levels $[38,39]$.

Our findings do not exclude fetal hypoxia as the prime factor in the metabolic disorders resulting from postmaturity. Indeed, experimental hypoxia in the fetal rat has been proved to decrease plasma insulin and increase plasma glucagon [40]. Furthermore, in postmature rabbits, chronic hypoxia [41] is well correlated with low liver glycogen content [42]. There is no data about hypoxia in the postmature fetal rat and we are now investigating this problem. Our results could be interpreted as being due to an increase in the relative fasting state of the fetus as a result of reduced placental transfer of glucose and/or other fuels, despite the fact that "prolonged" mothers have normal blood glucose levels. This problem is now under investigation using isotopic experiments and our preliminary results as well as the fact that the growth of the fetus is not inhibited do not favour a diminished transfer of glucose from the mother to the postmature fetus as compared to the term fetus. Of course, besides glucose, the availability of other glycogen precursors might be of importance.

One of the most intriguing effects of postmaturity is the lack of insulin accumulation in the fetal pancreas. This defect occurs in a period of high insulin stores $[16,18,43]$ and although it lasted at least five days, no evidence of diabetes was observed when the animals were examined three weeks later by a glucose tolerance test. This ability of the endocrine pancreas to exhibit functional recovery from an alteration in the hormonal accumulation has previously been noticed in neonatal rats submitted to streptozotocin-diabetes [16], but in these experiments, there was only partial recovery from diabetes even when the diabetic newborn rat became adult [44]. If the good functional recovery observed in postmature animals suggests that further development of diabetes is not likely to occur through an isolated and transient factor of impairment in islet growth, this factor may be of importance if associated with other causes of alteration of islet function.

Acknowledgements. In addition to those who gave us hormones (see Methods), we thank J. C. Cros, M. Protat for their excellent technical assistance and D. Lhenry for her careful preparation of the manuscript. This work was supported by the Universite Paris VII and the Institut National de la Santé et de la Recherche Médicale (INSERM) (Contrat de Recherche Libre $\mathrm{n}^{\circ}$ 76.1.022.4).

\section{References}

1. Portha, B., Rosselin, G., Picon, L.: Impairment of insulinogenesis and liver glycogen depletion in a model of prolonged gestation. Diabetologia 11 (Abstr. 223), 370-371 (1975)

2. Clifford, S. H.: Postmaturity with placental dysfunction. Clinical syndrome and pathologic findings. J. Pediat. 44, 1-13 (1954)

3. Vorherr, H.: Placental insufficiency in relation to postterm pregnancy and fetal postmaturity. Amer. J. Obstet. Gynec. 123, 67-103 (1975)

4. Flexner, L. B., Cowie, D. B., Hellman, L. M., Wilde, W. S., Wosburgh, G. J.: The permeability of the human placenta to sodium in normal and abnormal pregnancies. Amer. J. Obstet. Gynec. 55, 469-480 (1948)

5. Zuspan, F. P.: Problems and management of postmaturity and placental insufficiency. J. Reprod. Med. 4, 77-93 (1970)

6. Khattab, A. K., Forfar, J. O.: The interrelationship betwcen calcium phosphorus and glucose levels in mother and infant in conditions commonly associated with "placental insufficiency". Biol. Neonat. (Basel) 18, 1-16 (1971)

7. Boe, F.: Studies in prolonged pregnancy in rats. Acta path. microbiol. scand. 36 (Suppl.), 1-146 (1938)

8. Thliveris, J. A.: Ultrastructure of fetal liver at term and during prolonged gestation in the rat. Amer. J. Obstet. Gynec. 118, 864-871 (1974)

9. Thliveris, J. A., Connell, R. S.: Ultrastructure of the fetal rat adrenal gland at full-term and during prolonged gastation. Anat. Rec. 175, 607-624 (1973)

10. Eguchi, Y., Ariyuki, F.: Development of the fetal rat adrenal in prolonged pregnancy. Endocr. jap. 10, 125-135 (1963)

11. Picon, $L .:$ Effect of insulin on growth and biochemical composition of the rat fetus. Endocrinology 81, 1419-1421 (1967)

12. Van Marthens, E., Grauel, L., Zamenhof, S.: Enhancement of prenatal development in the rat by operative restriction of litter size. Biol. Neonat (Basel) 25, 53-56 (1974)

13. Asplund, K.: Effects of postnatal feeding on the functional maturation of pancreatic islet $\beta$-cells of the nconatal rats. Diabetologia 8, 153-159 (1972)

14. Lemonnier, D., Suquet, J. P., Aubert, R., Rossclin, G.: Longterm effect of mouse neonate food intake on adult body composition, insulin and glucose serum levels. Horm. Metab. Res. 5, 223-224 (1973)

15. Hugget, A. S., Nixon, D. A.: Use of glucose-oxydase peroxidase and $\mathrm{O}$-dianisidine in determination of blood and urinary glucose. Lancet 1957 II, 368-370 
16. Portha, B., Levacher, C., Picon, L., Rosselin, G.: Diabetogenic effect of streptozotocin in the rat during the perinatal period. Diabetes 23, 889-895 (1974)

17. Rosselin, G., Dolais, J.: Application de la méthode radio-immunologique au dosage de l'insuline humaine et au dosage de l'hormone folliculo-stimulante humaine (H. FSH). Monographie ann. Sté Fse Biol. Clin. "Les Isotopes - Applications biocliniques", Expansion Sci. Ed. 1, 189-217 (1967)

18. Jarrousse, C., Rançon, F., Rosselin, G.: Hormonogénèse périnatale de l'insuline et du glucagon chez le rat. C. R. Acad. Sci. (Paris) 276, 585-588 (1973)

19. Rosselin, G., Assan, R., Yalow, R. S., Berson, S. A.: Separation of antibody bound and unbound peptide hormone labeled with iodide 131 by talcum powder and precipitated silica. Nature 212, 355-357 (1966)

20. Dawkins, M. J. R.: Glycogen synthesis and breakdown in fetal and newborn rat liver. Ann. N. Y. Acad. Sci. 111, 203-211 (1963)

21. Cake; M. H., Yeung, D., Oliver, I. T.: The control of postnatal hypoglycemia - Suggestions based on experimental observations in neonatal rats. Biol. Neonat. (Basel) 18, 183-192 (1971)

22. Ballard, F, J.: Gluconeogenesis and the regulation of blood glucose in the neonate. In: Diabetes (eds. R. R. Rodrigues, J. Vallance-Owen), pp. 592-600. Amsterdam: Excerpta Medica 1971

23. Snell, K., Walker, D. G.: Glucose metabolism in the newborn rat. Hormonal effects in vivo. Biochem. J. 134, 899-906 (1973)

24. Yeung, D., Oliver, I. T.: Gluconeogenesis from amino acids in neonatal rat liver. Biochem. J. 103, 744-748 (1967)

25. Manns, J. G., Brockman, R. P.: The role of insulin in the synthesis of fetal glycogen. Canad. J. Physiol. Pharmacol. 47, 917-921 (1969)

26. Vinicor, F., Kohalmi, D., Clark, C. M.: Characterization of carbohydrate metabolism in the isolated fetal rat heart. Diabetes 23, 662-668 (1974)

27. Eisen, H. J., Goldfine, I. D., Glinsmann, W. H.: Regulation of hepatic glycogen synthesis during fetal development: Roles of hydrocortisone, insulin and insulin receptors. Proc. nat. Acad. Sci. (Wash.) 70, 3454-3457 (1973)

28. Schwartz, A. L., Raiha, N. C. R., Rall, W. T.: Hormonal regulation of glycogen metabolism in human fetal liver. I. Normal developments and effects of dibutyryl cyclic AMP, glucagon and insulin in liver explants. Diabetes 24, 1101-1112 (1975)

29. Wagle, S. R., Ingebretsen, W. R., Sampson, L.: Studies on the in vitro effects of insulin on glycogen synthesis and ultrastructure in isolated rat liver hepatocytes. Biochem. biophys. Res. Commun. 53, 937-943 (1973)

30. Miller, T. B., Larner, J.: Mechanism of control of hepatic glycogenesis by insulin. J. biol. Chem. 248, 3483-3488 (1973)

31. Greengard, O.: The hormonal regulation of enzymes in prenatal and postnatal rat liver. Biochem. J. 115, 19-24 (1969)

32. Hunter, D. J. S.: Changes in blood glucose and liver carbohydrate after intrauterine injection of glucagon into fetal rats. $J$. Endocr. 45, 367-374 (1969)
33. Girard, J. R., Cuendet, G. S., Marliss, E. B., Kervran, A., Rieutort, M., Assan, R.: Fuels, hormones and liver metabolism at term and during the early postnatal period in the rat. J. clin. Invest. 52, 3190-3200 (1973)

34. Greengard, O., Dewey, H. K.: Initiation by glucagon of the premature development of tyrosine aminotransferase, serine dehydratase and glucose-6-phosphatase in fetal rat liver. J. biol. Chem. 242, 2986-2991 (1967)

35. Jacquot, R. L., Kretchmer, N.: Effect of fetal decapitation on enzymes of glycogen metabolism. I. biol. Chem. 239, $1301-1304$ (1964)

36. Plas, C., Chapeville, F., Jacquot, R. L.: Development of glycogen storage ability under cortisol control in primary cultures of rat fetal hepatocytes. Develop. Biol. 32, 81-91 (1973)

37. Nwosu, U. C., Wallach, E. E., Boggs, T. R., Bongiovanni, A. M.: Possible adrenocortical insufficiency in postmature neonates. Amer. J. obstet. Gynec. 122, 969-974 (1975)

38. Sutter-Dub, M. T., Leclercq, R., Felix, J. M., Jacquot, R., Sutter, B. C. J.: Serum progesterone and immunoreactive insulin levels in the pregnant rat. Horm. Metab. Res. 5, 18-21 (1973)

39. Sutter-Dub, M. T., Leclercq, R., Sutter, B. C. J, Jacquot, R.: Plasma glucose progesterone and immunoreactive insulin levels in the lactating rat. Horm. Metab. Res. 6, 297-300 (1974)

40. Porte, D., Jr, Robertson, R. P.: Control of insulin secretion by catecholamines, stress and the sympathetic nervous system. Fed. Proc. 32, 1792-1796 (1973)

41. Barcroft, J., Young, J. M.: Internal oxygen environment of the brain of postmature rabbit embryos. J. exp. Biol. 21, 70 (1945)

42. Roux, J. F., Romney, S. L., Dinnerstein, A.: Environmental and aging effects of postmaturity on fetal development and carbohydrate metabolism. Amer. J. Obstet. Gynec. 90, 546-553 (1964)

43. Lazarow, A., Wells, L. J., Carpenter, A. M., Hegre, O. D., Leonard, R. J., Mc Evoy, R. C.: Islet differentiation, organ culture, and transplantation. The Banting memorial lecture 1973. Diabetes 22, 877-912 (1973)

44. Portha, B., Picon, L., Rosselin, G., Levacher, C.: Restauration fonctionnelle des cellules $\beta$ après diabète induit par la streptozotocine chez le rat nouveau-né. J. Physiol. (Paris) 71, 307 A (1975)

Received: March 22, 1976, and in revised form: May 29, 1976

Dr. B. Portha

Laboratoire de Physiologie Animale

Bâtiment L

Université Paris VII

2 Place Jussieu

F-75005 Paris

France 